\title{
ANALYSIS OF THE OPERATING COSTS OF SOME HARVESTING SYSTEMS IN EGYPT
}

\author{
Morgan, H. A. ${ }^{* * *}$, M. E. Badawy ${ }^{* * *}$ and I. A. Abdelmotaleb ${ }^{*}$
}

ABSTRACT

Harvesting machinery plays an important role in agricultural production, and contributes a major capital input cost in most agricultural business. The present study aimed to evaluate the most three common harvesting systems of wheat crop in Egypt based on total operating costs of each system. Three systems under the study are evaluated, namely: the first system: (multi-purpose combine harvester (Claas dominator 130), the second system: (tractor mounted vertical conveyor reaper windrower + local power thresher), and the third system: (self-propelled reaper binder + local power thresher). The results indicated that the depreciation and repair \& maintenance costs were the most important factors influencing the total cost. Depreciation was estimated by three different methods are a straight-line, declining balance and sum of the years' digit methods. The results also indicated that the minimum total operating cost was 243.97 L.E./fed resulted from the first system followed by the third system 522.01 L.E./fed then the second system 614.51 L.E./fed.

\section{INTRODUCTION}

$\mathrm{H}$ arvesting is a very important activity in any agriculture business. Larger machines, new technology, higher prices for parts, new machinery, and higher energy prices have caused machinery and power costs to rise in recent years. These results are in the need to make careful decisions on what equipment to use, which requires knowledge on the costs of owning and using these machines. ASABE, (2006) stated that the total cost of using a field machine includes charges for ownership and operation. Ownership costs are seemingly independent of use and are often called fixed costs or overhead costs. Costs for operation vary directly with the amount of use and are often called variable costs.

\footnotetext{
* Professor, Agric. Eng. Dept., Faculty of Agric., Kafrelsheikh University.

${ }^{* *}$ Head Researcher, Agricultural Engineering Res. Inst. Dokki, Giza.

${ }^{* * *}$ Assistant Researcher, Agricultural Engineering Res. Inst. Dokki, Giza.
} 
Hunt, (1983) reported that, annual costs of operating a machine can be divided into two categories, fixed costs and variable costs. Fixed costs are independent on machinery use and include the following items: - aDepreciation; b- Taxes; c- Insurance; d- Interest and shelter. Variable costs are those varying in proportion to the amount of machine use. It is including the following items: a- Repair and maintenance; b- Fuel and lubricant; cLabor cost. Edwards, (2005) stated that depreciation is a cost resulting from wear, obsolescence, and age of a machine. The degree of mechanical wear may cause the value of a particular machine to be somewhat above or below the average value for similar machines when it is traded or sold. Hunt, (1979) stated that repair and maintenance costs are expected to vary from one part of the country to another, because of differences in soils, weather and crop condition. He mentioned that some variations are due to differences in the skill of machine operators and the value of machines. Witney and Saddaoun (1989) reported that, as repair costs tend to increase with machine age, they are important in influencing the optimal time for machinery replacement. Ismail et al. (2009) indicted that the harvesting costs make up 35\% of the total machinery costs. This emphasizes the need for developing robust methods for choosing the optimal harvesting equipment. The objective of this study is to evaluate the most three harvesting systems of wheat crop in Egypt based on total operating costs of each system.

\section{MATERIALS AND METHODS}

This study was carried out in the Rice Mechanization Center (RMC), Meet El-Deeba, Kafr-Elsheikh Governorate, Egypt, using the most common systems to harvest wheat crop (gemmeza 11) during agriculture season 2017/2018.

\section{Three harvesting systems of wheat crop were studied as follows:}

The first system: multi-purpose combine harvester (Class dominator 130).

The second system: tractor mounted vertical conveyor reaper windrower +local power thresher.

The third system: self-propelled reaper binder + local power thresher.

\section{The parameters were studied as follows:}

\section{1- System types:}

Three types of harvesting systems which were mentioned above were evaluated. The implement service costs and technical specifications of the harvesting systems components are shown in Tables 1 and 2. 


\section{2- Forward speed:}

The first system: Four forward speeds, $(1.6,2.4,3$ and 4.5$) \mathrm{km} / \mathrm{h}$

The second system: Four forward speeds, $(1.77,2.88,3.6$ and 4.32$) \mathrm{km} / \mathrm{h}$

The third system: Four forward speed, $(1.85,2.54,3.44$ and 4.25$) \mathrm{km} / \mathrm{h}$

\section{3- Threshing cylinder speed:}

The second and Third systems: Four threshing drum speed, $(25,28.8,32.6$ and 34.4$) \mathrm{m} / \mathrm{s}$.

4- Machine age. Machine age was estimated as shown in Table 5.

5- Depreciation estimation methods. Three methods were used to estimate depreciation including, straight line method, declining-balance method and sum of the years' digit method.

Table 1: Implement service costs.

\begin{tabular}{|l|c|c|c|c|}
\hline \multicolumn{1}{|c|}{ Machine } & $\begin{array}{c}\text { Purchase } \\
\text { price, } \\
\text { L.E. }\end{array}$ & $\begin{array}{c}\text { No. } \\
\text { labors }\end{array}$ & $\begin{array}{c}\text { Inflation } \\
\text { rate* }\end{array}$ & $\begin{array}{c}\text { Fuel } \\
\text { price, } \\
\text { L.E./I }\end{array}$ \\
\hline Combine harvester & 1200000 & 1 & & \\
\hline Tractor & 40000 & 1 & & \\
\hline Mounted reaper & 10000 & - & \multirow{2}{*}{$13 \%$} & \multirow{2}{*}{5.5} \\
\cline { 1 - 3 } Reaper binder & 80000 & 1 & & \\
\cline { 1 - 2 } Tractor (Nasr) & 80000 & 1 & & \\
\hline Thresher (the second system) & \multirow{2}{*}{17000} & 8 & & \\
\cline { 1 - 2 } Thresher (the third system) & & 5 & & \\
\hline
\end{tabular}

* source: Central Bank of Egypt (average of last 10 years)

\section{Depreciation (D):}

It is the loss in value and service capacity. The following formulas were used to calculate average annual depreciation costs in this study.

\section{Straight line method:}

The annual depreciation charge is expressed by the following equation according to (Hunt,1983):

$$
\mathbf{D}=(\mathbf{P}-\mathbf{S}) / \mathbf{L}
$$

Where:

$\mathrm{D}=$ Depreciation (L.E./year).

$\mathrm{P}=$ Purchase Price (L.E.).

$\mathrm{S}=$ Salvage value or selling price (L.E.), $10 \%$ of purchase price

$\mathrm{L}=$ Time between selling and purchasing, years. 
Table 2: The technical specifications of the harvesting machines component

\begin{tabular}{|c|c|c|c|c|}
\hline Item & Claas & $\begin{array}{c}\text { Tractor mounted } \\
\text { vertical conveyor } \\
\text { reaper windrower }\end{array}$ & $\begin{array}{c}\text { Self-propelled } \\
\text { reaper binder }\end{array}$ & $\begin{array}{c}\text { Local power } \\
\text { thresher }\end{array}$ \\
\hline Model & Dominator 130 & $\begin{array}{c}\text { YTO-ME350, } \\
\text { local mounted reaper }\end{array}$ & $\begin{array}{c}\text { BCS reaper binder } \\
622\end{array}$ & Egypt super \\
\hline Cutting width, mm & 4200 & 1800 & 1200 & $\ldots \ldots \ldots$ \\
\hline $\begin{array}{c}\text { Threshing drum } \\
\text { diameter, } \mathbf{m m}\end{array}$ & 450 & $\ldots \ldots \ldots \ldots$ & $\ldots \ldots$ \\
\hline $\begin{array}{c}\text { Dimensions, } \mathbf{m m} \\
(\mathbf{L} \times \mathbf{W} \times \mathbf{H})\end{array}$ & $7200 \times 4200 \times 3700$ & $3540 \times 1480 \times 2670$ & $3600 \times 1850 \times 1300$ & $4400 \times 2200 \times 2200$ \\
\hline Engine power, hp & 125 & 35 & 10.2 & 65 \\
\hline \multicolumn{1}{|c|}{ Engine type } & 6 cylinders & $\begin{array}{c}\text { S-cylinder, } \\
\text { water cooled }\end{array}$ & $\begin{array}{c}\text { Lombardini } 3 \text { LD } 450 \\
\text { air cooled diesel } \\
\text { engine }\end{array}$ & $\begin{array}{c}\text { Nasr tractor was } \\
\text { used as a power } \\
\text { source }\end{array}$ \\
\hline
\end{tabular}




\section{Declining-balance method:}

The depreciation amount is different for each year of the tractor's or machine's life. Depreciation can be expressed by the following equation according to (Bowers, 1981):

$$
\begin{aligned}
& \mathbf{D}=\mathbf{V}_{\mathbf{n}}-\mathbf{V}_{(\mathbf{n}+\mathbf{1})} \\
& V_{n}=P\left(1-\frac{X}{L}\right)^{n} \quad \quad V_{(n+1)}=P\left(1-\frac{X}{L}\right)^{n+1}
\end{aligned}
$$

Where:

$\mathrm{D}=$ Amount of depreciation charged for year $\mathrm{n}+1$ (L.E./year) $\mathrm{P}=$ Purchase price (L.E.).

$\mathrm{n}=$ Number representing age of the machine in years at beginning of year. $\mathrm{V}=$ Remaining value at any time (L.E.).

$\mathrm{X}=$ Ratio of depreciation rate used to that of straight line method. It will be between 1 and 2 normally (we will use this ratio at 1.5)

$\mathrm{L}=$ Time between selling and purchasing, years.

\section{Sum of the years' digit method:}

The annual depreciation charge is expressed by the following equation according to (Hunt,1983).

$$
\mathbf{D}=\frac{\mathbf{L}-\mathbf{n}}{\mathbf{Y D}}(\mathbf{P}-\mathbf{S})
$$

Where:

$\mathrm{D}=$ Depreciation (L.E./year).

$\mathrm{P}=$ Purchase Price (L.E.).

$\mathrm{S}=$ Salvage Value or selling price (L.E.), $10 \%$ of purchase price

$\mathrm{L}=$ Time between selling and purchasing, years.

$\mathrm{YD}=$ Sum of the years digits, $(1+2+3+\ldots . .+\mathrm{L})$.

$\mathrm{n}=$ Age of the tractors or machines in years at the beginning of the year.

Taxes, Housing, Interest on investment and Insurance, (THII):

The annual THII is expressed by the following equation (Kepner et al., 1982).

$$
\text { THII }=\frac{\mathbf{P}+\mathbf{S}}{2} \times \mathbf{A M I}
$$

Where:

THII $=$ Taxes, Housing, Interest on investment and Insurance,

L.E/year;

$\mathrm{P}=$ Purchase price of the machine. L.E; 
$\mathrm{S}=$ Salvage value or selling price (L.E.), $10 \%$ of purchase price $\mathrm{AMI}=$ Percentage of average machine investment (AMI) charged for taxes, housing, interest, and insurance (THII factor), (see Table 3).

\section{Repair and Maintenance $(\mathbf{R} \& M)$ :}

Accumulated repair and maintenance costs at a typical field speed can be determined with the following relationship using the repair and maintenance factors $\mathrm{RF}_{1}$ and $\mathrm{RF}_{2}$ and the accumulated use of the machine.

\section{(ASABE,2006)}

$$
\mathbf{C}_{\mathbf{R} \& M}=(\mathbf{R F 1}) \mathbf{P}\left[\frac{\mathbf{h}}{\mathbf{1 0 0 0}}\right]^{(\mathrm{RF} 2)}
$$

Where:

$\mathrm{C}_{\mathrm{R \& M}}=$ Accumulated repair and maintenance cost.

$\mathrm{P}=$ Purchase price (L.E.) In time of rapid inflation, the original purchase price must be multiplied by $(1+i)^{n}$ where $i$ is the average inflation rate and $\mathrm{n}$ is the age of the machine.

$\mathrm{RF}_{1}$ and $\mathrm{RF}_{2}=$ Repair and maintenance factors, (see Table 4).

$\mathrm{h}=$ Accumulated use of machine, $\mathrm{h}$.

Table 3: Percentage of average machine investment (AMI) charged for property taxes, housing, interest, and insurance (THII factor) (ASABE,2004).

\begin{tabular}{|lccccc|}
\hline \multicolumn{1}{|c}{ Machinery } & $\begin{array}{c}\text { Taxes } \\
(\mathbf{\%})\end{array}$ & $\begin{array}{c}\text { Housing } \\
(\mathbf{\%})\end{array}$ & $\begin{array}{c}\text { Interest } \\
(\mathbf{\%})\end{array}$ & $\begin{array}{c}\text { Insurance } \\
(\mathbf{\%})\end{array}$ & $\begin{array}{c}\text { Total } \\
(\mathbf{\%})\end{array}$ \\
\hline Wheel tractor & 1.4 & 0.3 & 8.0 & 0.9 & 10.6 \\
\hline Combine & 1.4 & 0.5 & 8.0 & 2.1 & 12.0 \\
\hline $\begin{array}{l}\text { Self-propelled } \\
\text { binder }\end{array}$ & 1.4 & 1.1 & 8.0 & 2.1 & 12.6 \\
\hline $\begin{array}{l}\text { Reaper } \\
\text { windrower }\end{array}$ & 1.4 & 1.1 & 8.0 & 0.6 & 11.1 \\
\hline
\end{tabular}

Table 4: Useful life, and repair and maintenance cost parameters (ASABE,2004).

\begin{tabular}{|l|c|c|c|}
\hline \multirow{2}{*}{ Machinery } & Estimated life & \multicolumn{2}{c|}{ Repair factors } \\
\cline { 3 - 4 } & (hour) & RF1 & RF2 $^{*}$ \\
\hline 2 - wheel drive & 12000 & 0.007 & 2.00 \\
\hline Combine (self-propelled) & 3000 & 0.04 & 2.10 \\
\hline Self-propelled binder & 2500 & 0.18 & 1.60 \\
\hline Reaper windrower & 2500 & 0.18 & 1.60 \\
\hline Thresher & 3000 & 0.28 & 1.40 \\
\hline
\end{tabular}




\section{Fuel cost:}

Refill method is used to determine the fuel consumption by:

- Filling up to the fuel tank filler neck.

- Travelling distance of the machine.

- Refilling to the fuel tank filler neck and recoding of volume by a measure jar.

- from these observations, the volume of fuel consumed was determined and the rate of fuel consumption was calculated as follow;

$$
\text { Fuel consumption }=\frac{\text { Fuel consumption, } \mathbf{m l}}{\text { Time consumpion, } \mathbf{s e c}} \times 3.6 \mathrm{l} / \mathrm{h} \ldots \text {... (7) }
$$

Fuel and lubricants can be calculated according to $(\boldsymbol{A S A B E}, 2006)$ as follows:

Fuel cost $=$ Fuel consumption $(\mathbf{l} / \mathbf{h}) \times$ price of fuel $(\mathrm{L} . \mathrm{E} / \mathrm{l})$

\section{Lubrication cost:}

Oil, grease and lubricant (OGL) can be taken as $15 \%$ of the fuel cost. (ASABE,2006).

Labor (l):

Labor wage was considered 100 L.E/day. The day work is 8 hours so that the labor wage was $12.5 \mathrm{~L} . \mathrm{E} / \mathrm{h}$.

\section{Total costs:}

The total costs (L.E/h.) include the total fixed costs (L.E/h.) plus total variable costs (L.E/h.) The methodology of estimating total costs (L.E/h.) or (L.E/fed) was as follows (Hunt, 1983).

Total costs $(\mathrm{L} . \mathrm{E} / \mathrm{h})=$. fixed costs $(\mathrm{L} . \mathrm{E} / \mathrm{h})+$. variable costs $(\mathrm{L} . \mathrm{E} / \mathrm{h}$. operating cost $(\mathrm{L} . \mathrm{E} / \mathrm{fed})=$ the total costs $(\mathrm{L} . \mathrm{E} / \mathrm{h}) /$ the effective field capacity (fed/h).

\section{RESULTS AND DISCUSSION}

The obtained data will be discussed under the following headings:

Effect of machine age and forward speed on total operating costs of the first system (Combine harvester "Class Dominator 130").

Figure 1 shows the relationship between combine harvester age and both depreciation and repair \& maintenance costs. Also, the results in Figure 1 indicate that by increasing the machine age tend to decrease the depreciation values from 600 to 138.97 and from 654.55 to 65.45 L.E./h in both declining balance and sum of years' digit methods, respectively. 
On the other side, the depreciation was fixed in a straight-line method and recorded 360 L.E./h. However, by increasing the machine age the repair \& maintenance costs increased, where the values recorded 14.40 L.E./h in the first year, while, the values increased to 432.58 L.E./h in the tenth year, these increase due to the increase in both the machine current list price and the accumulated hours of use over the age of machine.

On the other hand, Table 5 shows the relationship between combine harvester age, forward speed and depreciation estimation method on total operating costs (L.E./fed). The results indicated that by increasing machine forward speeds tend to decrease in total costs in case of using all depreciation estimating methods, this result is may be due to increase in actual field capacity. While, by increasing machine age tend to increase the total costs at all forward speeds in case of estimate the depreciation by a straight-line method. while, in case of sum of the years' digits method, the total costs were high (333.41 L.E/fed) at first year and drop to their lowest value $(272.21 \mathrm{~L} . \mathrm{E} / \mathrm{fed})$ in the eighth year at forward speed of $4.5 \mathrm{~km} / \mathrm{h}$. While, in the declined balance method the total costs were high (316.85 L.E/fed) at first year and drop to their lowest value (303.84 L.E/fed) in the sixth year at forward speed of $4.5 \mathrm{~km} / \mathrm{h}$ and then the total costs begin to rise duo to increase in repair \& maintenance costs with age in both declined balance and sum of the years' digit methods.

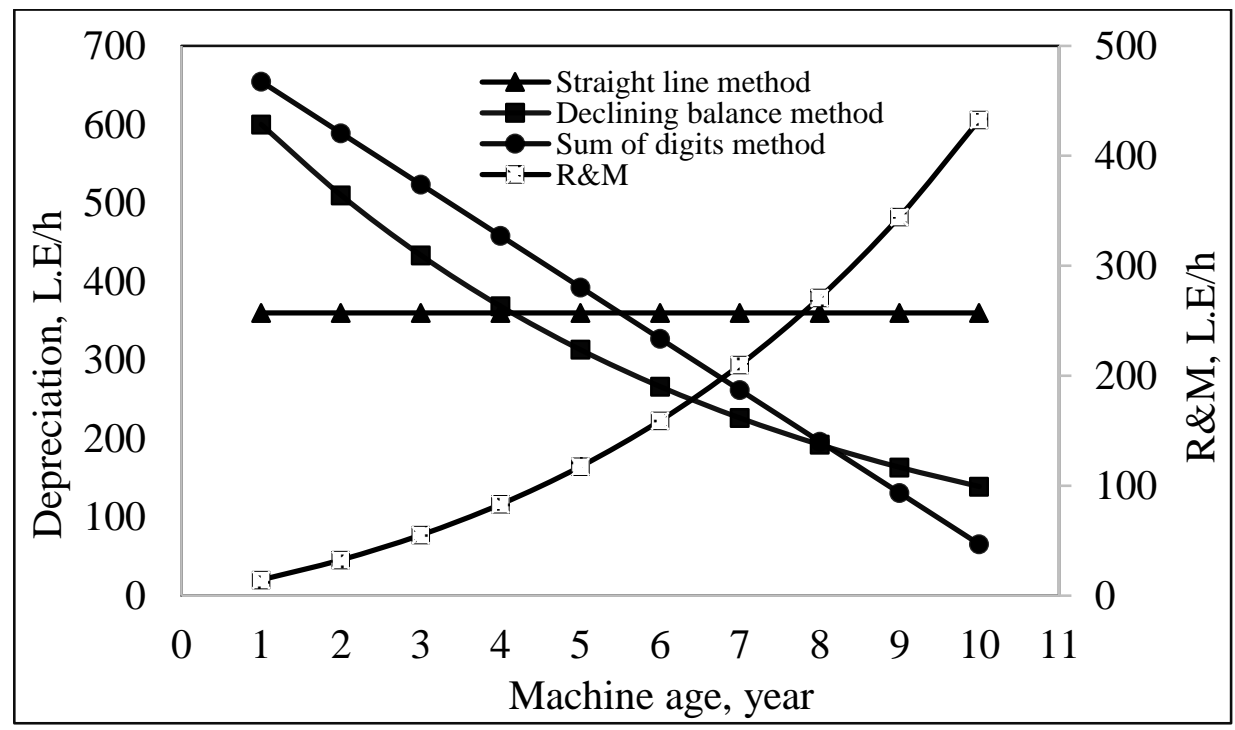

Figure 1: Effect of machine age on depreciation and repair $\&$ maintenance costs of the first system (L.E/h). 
Table 5. Total operating cost of the first system, at different forward speeds and machine age, (L.E./fed).

\begin{tabular}{|c|c|c|c|c|c|c|c|c|c|c|c|c|}
\hline \multirow{4}{*}{$\begin{array}{l}\text { Machine } \\
\text { age, year }\end{array}$} & \multicolumn{12}{|c|}{ Total cost, L.E/fed } \\
\hline & \multicolumn{4}{|c|}{ Straight line method } & \multicolumn{4}{|c|}{ Declining balance method } & \multicolumn{4}{|c|}{ sum of the years' digit } \\
\hline & \multicolumn{4}{|c|}{ Forward speed, $\mathrm{km} / \mathrm{h}$} & \multicolumn{4}{|c|}{ Forward speed, km/h } & \multicolumn{4}{|c|}{ Forward speed, $\mathrm{km} / \mathrm{h}$} \\
\hline & 1.6 & 2.4 & 3 & 4.5 & 1.6 & 2.4 & 3 & 4.5 & 1.6 & 2.4 & 3 & 4.5 \\
\hline 1 & 587.01 & 412.00 & 341.17 & 243.97 & 781.60 & 543.63 & 447.84 & 316.85 & 825.83 & 573.54 & 472.08 & 333.41 \\
\hline 2 & 601.72 & 421.95 & 349.24 & 249.48 & 723.34 & 504.22 & 415.90 & 295.03 & 787.47 & 547.60 & 451.05 & 319.04 \\
\hline 3 & 620.06 & 434.36 & 359.29 & 256.35 & 679.65 & 474.67 & 391.96 & 278.67 & 752.74 & 524.10 & 432.02 & 306.04 \\
\hline 4 & 642.72 & 449.68 & 371.71 & 264.84 & 649.59 & 454.33 & 375.48 & 267.41 & 722.33 & 503.53 & 415.35 & 294.65 \\
\hline 5 & 670.52 & 468.49 & 386.95 & 275.25 & 632.57 & 442.82 & 366.15 & 261.04 & 697.05 & 486.44 & 401.49 & 285.18 \\
\hline 6 & 704.40 & 491.41 & 405.52 & 287.94 & 628.37 & 439.98 & 363.84 & 259.46 & 677.87 & 473.46 & 390.98 & 278.00 \\
\hline 7 & 745.49 & 519.20 & 428.04 & 303.32 & 637.07 & 445.87 & 368.62 & 262.72 & 665.88 & 465.35 & 384.41 & 273.51 \\
\hline 8 & 795.08 & 552.74 & 455.23 & 321.89 & 659.14 & 460.79 & 380.71 & 270.99 & 662.40 & 463.00 & 382.50 & 272.21 \\
\hline 9 & 854.68 & 593.06 & 487.90 & 344.21 & 695.35 & 485.29 & 400.56 & 284.55 & 668.93 & 467.42 & 386.08 & 274.65 \\
\hline 10 & 926.07 & 641.35 & 527.03 & 370.95 & 746.86 & 520.13 & 428.80 & 303.84 & 687.25 & 479.81 & 396.12 & 281.51 \\
\hline
\end{tabular}




\section{Effect of machine age and forward speed on total operating costs of the second system (tractor mounted vertical conveyor reaper windrower + local power thresher).}

The second system includes two main stages, the first stage is the harvesting stage (tractor mounted vertical conveyor reaper windrower) and the second stage is the threshing stage (local power thresher).

The data presented in Figures 2 and 3 illustrate the relationship between machine age and both depreciation and repair \& maintenance costs (L.E/h) of the second system (harvesting and threshing stage). Figures 2 and 3 shows that by increasing the machine age tend to decrease the depreciation values by $76.82 \%$ and by $90 \%$ in both declined balance and sum of the years' digit methods, respectively. On the other hand, the depreciation was fixed in the straight-line method and recorded 6.60 and 11.10 L.E./h for harvesting and threshing stage, respectively. While, by increasing the machines age tend to increase repair \& maintenance costs from 1.12 to 19.46 and from 3.61 to 42.38 L.E./h for harvesting and threshing stage, respectively. Also, increasing forward speed from 1.77 to $4.32 \mathrm{~km} / \mathrm{h}$ tend to increase fuel and oil costs by $75.88 \%$ for harvesting stage while at threshing stage, fuel and oil costs increased by $49 \%$ when threshing drum speed increased from 25 to $34.40 \mathrm{~m} / \mathrm{s}$.

However, at harvesting stage, increasing the forward speed from 1.77 to $4.32 \mathrm{~km} / \mathrm{h}$ decreased the total costs (L.E./fed) by $48.5 \%$ at all depreciation estimation method as shown in Table 6.

Also, at threshing stage, increasing threshing drum speed from 25 to 34.40 $\mathrm{km} / \mathrm{h}$ tends to decrease the total costs (L.E./fed) by about $22 \%$ at all depreciation estimation methods as shown in Table 7.

Effect of machine age and forward speed on total operating costs of the third system (reaper binder + local power thresher).

The third system includes two main stages, the first stage is the harvesting stage (reaper binder) and the second stage is the threshing stage (local power thresher).

Analysis of depreciation and repair \& maintenance costs (L.E./h) of the third system (harvesting stage) are shown in Figure 4. The results show that the depreciation was fixed in a straight-line method and recorded 25.20 L.E./h. 


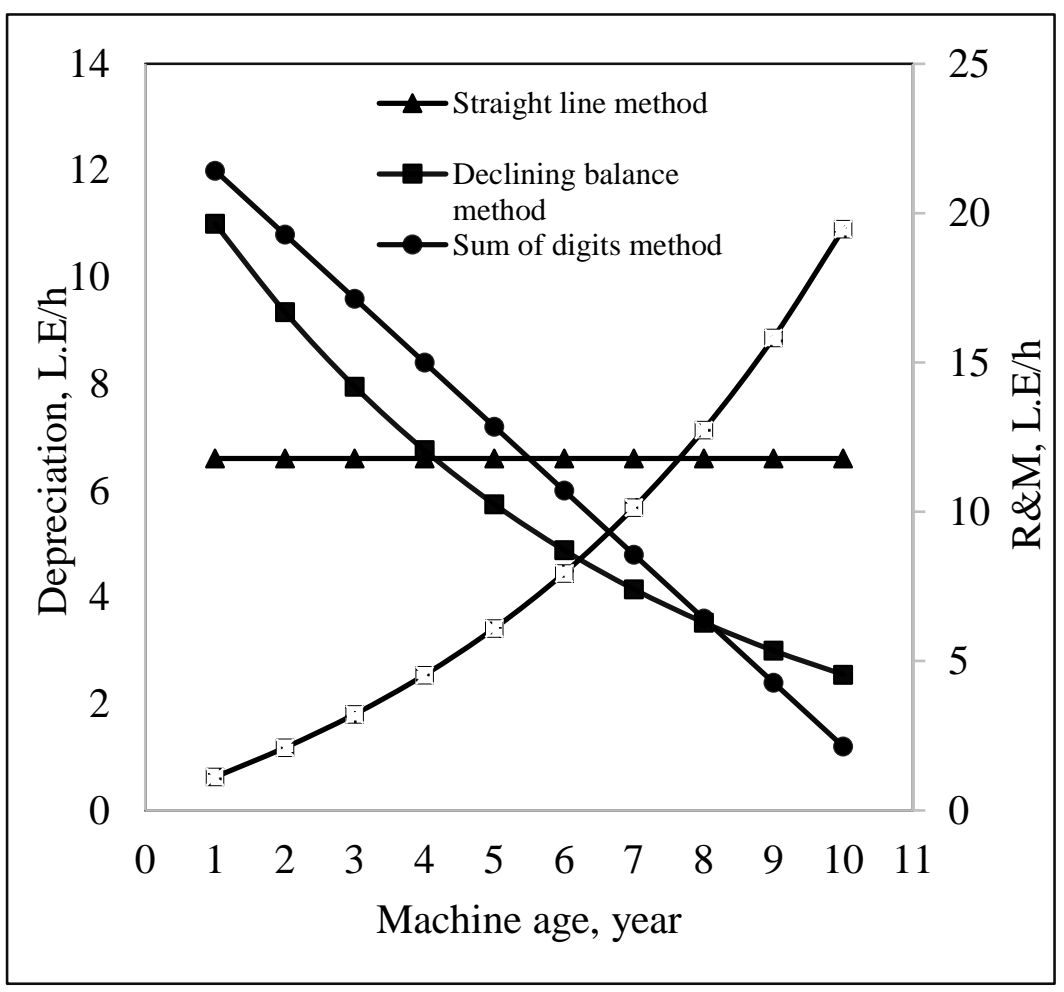

Figure 2: Effect of machine age on depreciation and repair \& maintenance costs of the second system (harvesting stage), (L.E/h).

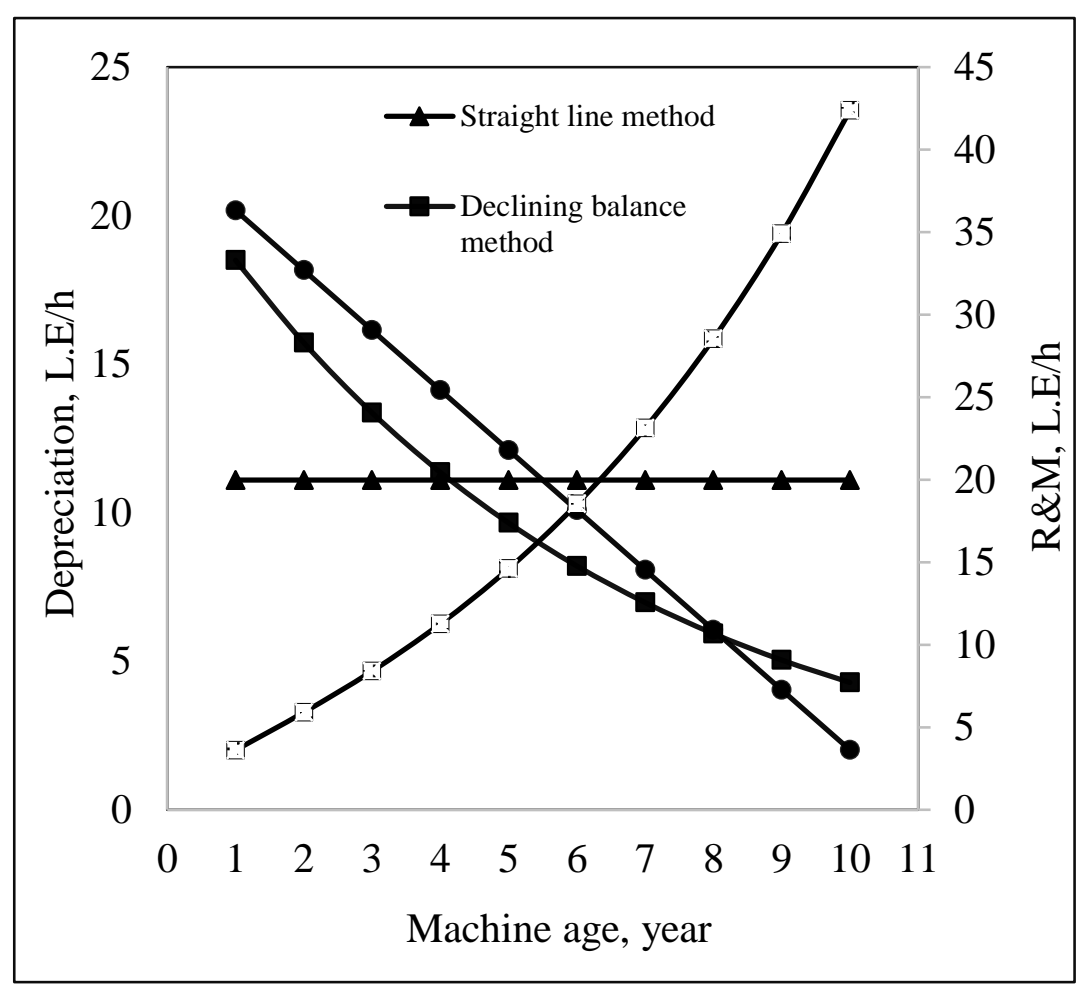

Figure 3: Effect of machine age on depreciation and repair \& maintenance costs of the second system (threshing stage), (L.E/h) 
Table 6. Total operating cost of the second system (harvesting stage), at different forward speeds and machine age, L.E./fed.

\begin{tabular}{|c|c|c|c|c|c|c|c|c|c|c|c|c|}
\hline \multirow{4}{*}{$\begin{array}{l}\text { Machine } \\
\text { age, year }\end{array}$} & \multicolumn{12}{|c|}{ Total cost, L.E/fed } \\
\hline & \multirow{2}{*}{\multicolumn{4}{|c|}{$\begin{array}{c}\text { Straight line method } \\
\text { Forward speed, km/h }\end{array}$}} & \multirow{2}{*}{\multicolumn{4}{|c|}{$\begin{array}{c}\text { Declining balance method } \\
\text { Forward speed, } \mathbf{k m} / \mathbf{h}\end{array}$}} & \multirow{2}{*}{\multicolumn{4}{|c|}{$\begin{array}{l}\text { sum of the years' digit } \\
\text { Forward speed. } \mathrm{km} / \mathrm{h}\end{array}$}} \\
\hline & & & & & & & & & & & & \\
\hline & 1.77 & 2.88 & 3.6 & 4.32 & 1.77 & 2.88 & 3.6 & 4.32 & 1.77 & 2.88 & 3.6 & 4.32 \\
\hline 1 & 123.37 & 87.03 & 74.59 & 65.16 & 130.40 & 91.59 & 78.34 & 68.35 & 131.99 & 92.63 & 79.20 & 69.07 \\
\hline 2 & 124.94 & 88.04 & 75.43 & 65.87 & 129.33 & 90.90 & 77.78 & 67.86 & 131.64 & 92.40 & 79.01 & 68.91 \\
\hline 3 & 126.73 & 89.21 & 76.39 & 66.68 & 128.88 & 90.61 & 77.53 & 67.66 & 131.52 & 92.32 & 78.94 & 68.86 \\
\hline 4 & 128.83 & 90.57 & 77.51 & 67.63 & 129.07 & 90.73 & 77.64 & 67.75 & 131.70 & 92.44 & 79.04 & 68.94 \\
\hline 5 & 131.31 & 92.19 & 78.83 & 68.76 & 129.94 & 91.30 & 78.10 & 68.14 & 132.27 & 92.81 & 79.35 & 69.20 \\
\hline 6 & 134.26 & 94.11 & 80.41 & 70.11 & 131.52 & 92.33 & 78.95 & 68.86 & 133.31 & 93.49 & 79.90 & 69.67 \\
\hline 7 & 137.77 & 96.39 & 82.28 & 71.70 & 133.86 & 93.84 & 80.19 & 69.92 & 134.90 & 94.52 & 80.75 & 70.39 \\
\hline 8 & 141.92 & 99.09 & 84.50 & 73.59 & 137.02 & 95.90 & 81.88 & 71.36 & 137.13 & 95.98 & 81.94 & 71.41 \\
\hline 9 & 146.84 & 102.29 & 87.13 & 75.82 & 141.09 & 98.55 & 84.06 & 73.21 & 140.14 & 97.93 & 83.55 & 72.78 \\
\hline 10 & 152.65 & 106.07 & 90.23 & 78.46 & 146.18 & 101.86 & 86.78 & 75.52 & 144.03 & 100.46 & 85.63 & 74.55 \\
\hline
\end{tabular}

Table 7. Total operating cost of the second system (threshing stage), at different threshing drum speeds and machine age, L.E./fed.

\begin{tabular}{|c|c|c|c|c|c|c|c|c|c|c|c|c|}
\hline \multirow{4}{*}{$\begin{array}{l}\text { Machine } \\
\text { age, year }\end{array}$} & \multicolumn{12}{|c|}{ Total cost, L.E/fed } \\
\hline & \multirow{2}{*}{\multicolumn{4}{|c|}{$\begin{array}{c}\text { Straight line method } \\
\text { Threshing drum speed, } \mathrm{m} / \mathrm{s}\end{array}$}} & \multirow{2}{*}{\multicolumn{4}{|c|}{$\begin{array}{l}\text { Declining balance method } \\
\text { Threshing drum speed, } \mathrm{m} / \mathrm{s}\end{array}$}} & \multirow{2}{*}{\multicolumn{4}{|c|}{$\begin{array}{c}\text { sum of the years' digit } \\
\text { Threshing drum speed, } \mathbf{m} / \mathbf{s}\end{array}$}} \\
\hline & & & & & & & & & & & & \\
\hline & 25 & 28.8 & 32.6 & 34.4 & 25 & 28.8 & 32.6 & 34.4 & 25 & 28.8 & 32.6 & 34.4 \\
\hline 1 & 698.55 & 630.84 & 568.78 & 549.35 & 728.55 & 656.96 & 591.43 & 570.69 & 735.36 & 662.90 & 596.58 & $\mathbf{5 7 5 . 5 4}$ \\
\hline 2 & 707.83 & 638.93 & 575.79 & 555.95 & 726.58 & 655.25 & 589.95 & 569.29 & 736.47 & 663.86 & 597.42 & 576.33 \\
\hline 3 & 717.96 & 647.74 & 583.44 & 563.16 & 727.15 & 655.74 & 590.38 & 569.70 & 738.41 & 665.55 & 598.88 & 577.71 \\
\hline 4 & 729.57 & 657.85 & 592.21 & 571.42 & 730.63 & 658.78 & 593.01 & 572.18 & 741.85 & 668.54 & 601.48 & 580.16 \\
\hline 5 & 743.11 & 669.64 & 602.43 & 581.06 & 737.26 & 664.55 & 598.02 & 576.89 & 747.20 & 673.20 & 605.52 & 583.97 \\
\hline 6 & 758.99 & 683.47 & 614.42 & 592.36 & 747.27 & 673.26 & 605.57 & 584.02 & 754.90 & 679.91 & 611.34 & 589.45 \\
\hline 7 & 777.66 & 699.72 & 628.52 & 605.64 & 760.95 & 685.17 & 615.90 & 593.75 & 765.39 & 689.03 & 619.25 & 596.91 \\
\hline 8 & 799.61 & 718.83 & 645.09 & 621.26 & 778.65 & 700.58 & 629.27 & 606.35 & 779.16 & 701.02 & 629.65 & 606.70 \\
\hline 9 & 825.41 & 741.29 & 664.57 & 639.61 & 800.84 & 719.90 & 646.03 & 622.13 & 796.77 & 716.36 & 642.95 & 619.24 \\
\hline 10 & 855.70 & 767.66 & 687.45 & 661.17 & 828.07 & 743.61 & 666.58 & 641.51 & 818.88 & 735.60 & 659.65 & 634.97 \\
\hline
\end{tabular}


On the other hand, by increasing the machine age the depreciation values decreased from 42 to 9.73 and from 45.82 to 4.58 L.E./h in both declined balance and sum of the years' digit methods, respectively. While, by increasing the machine age tend to increase repair \& maintenance costs from 5.48 to 165.50 L.E./h. The data presented in Table 8 show the effect of machine forward speed on total costs (L.E/fed). The results indicated that increasing forward speed from 1.85 to 4.25 tend to decrease the total costs from 160.69 to $80.84,199.92$ to 99.54 and from 208.84 to 103.79 L.E/fed at the first year when estimating the depreciation by straight-line, declining balance and sum of the years' digit methods, respectively.

However, at threshing stage, Figure 5 shows that by increasing the machine age tend to decrease the depreciation values from 18.50 to 4.28 and from 20.18 to 2.02 L.E./h in both declined balance and sum of years' digit methods, respectively. While, the depreciation was fixed in a straight-line method and recorded 11.10 L.E./h. While, increasing the machine age tend to increase repair \& maintenance costs from 3.61 to 42.38 L.E./h. While, the data tabulated in Table 9 indicates that the increasing threshing drum speed tend to decrease in total costs (L.E./fed) for all depreciation estimation methods. The minimum value of total costs for threshing stage was $441.17,461.12$ and 467.37 L.E./fed at straight-line, declining balance and sum of the years' digits methods, respectively and threshing drum speed of $34.40 \mathrm{~m} / \mathrm{s}$.

\section{CONCLUSION}

- There are many variables that affect overall operating costs such as machine age, purchase price, depreciation, accumulated hours, fuel price, fuel consumption, labor costs and repair \& maintenance costs. The results indicated that the depreciation and repair \& maintenance costs were the most important factors that influencing the total cost. The results also show that the forward speeds of the machine and machine age has a dramatic effect on total operating costs.

- The results showed that by increasing machine age tend to decrease the depreciation values by 76.82 and $90 \%$ in both declining balance and sum of the years' digit methods, respectively. On the other hand, the depreciation was fixed in a straight-line method. While, increasing machine age tend to increase repair \& maintenance costs and total costs for all harvesting systems.

- From this study, we recommend using the first system in large holdings and the third system in the case of small holdings. 


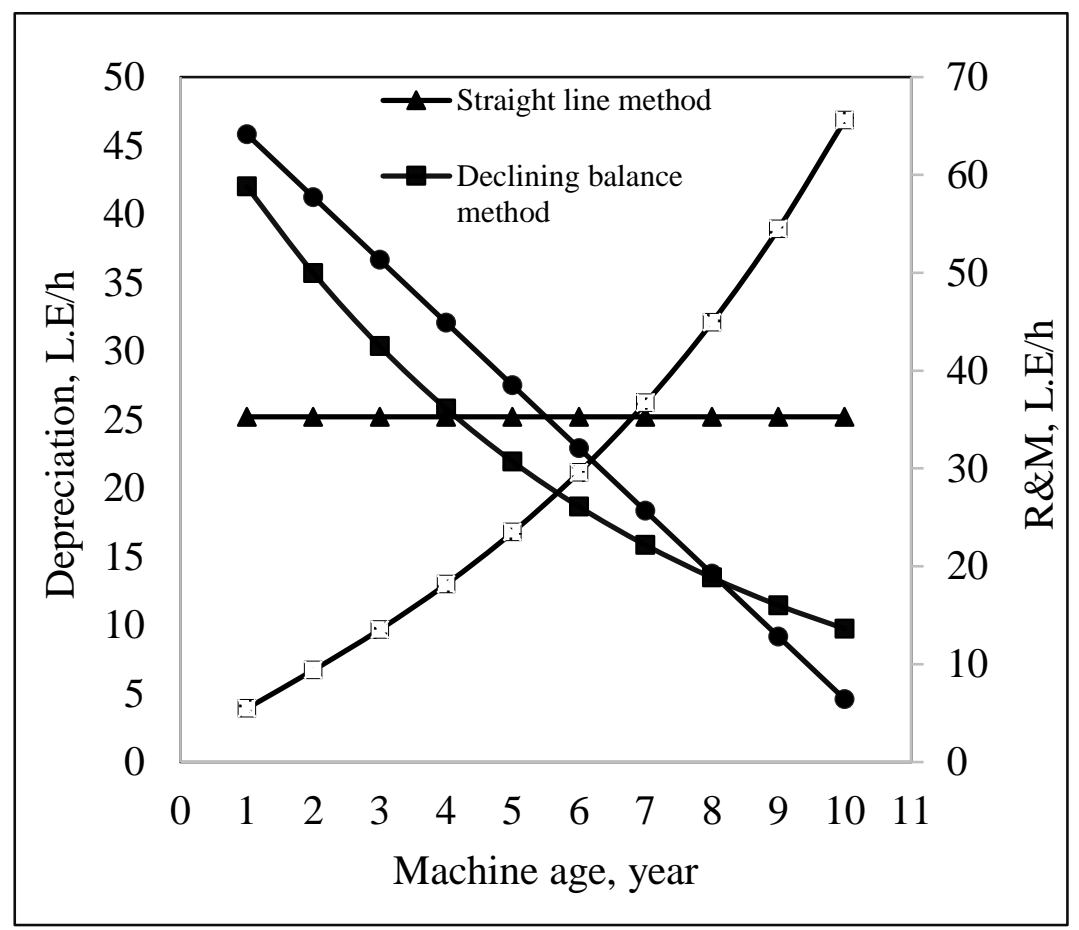

Figure 4: Effect of machine age on depreciation and repair \& maintenance costs of the third system (harvesting stage), (L.E/h).

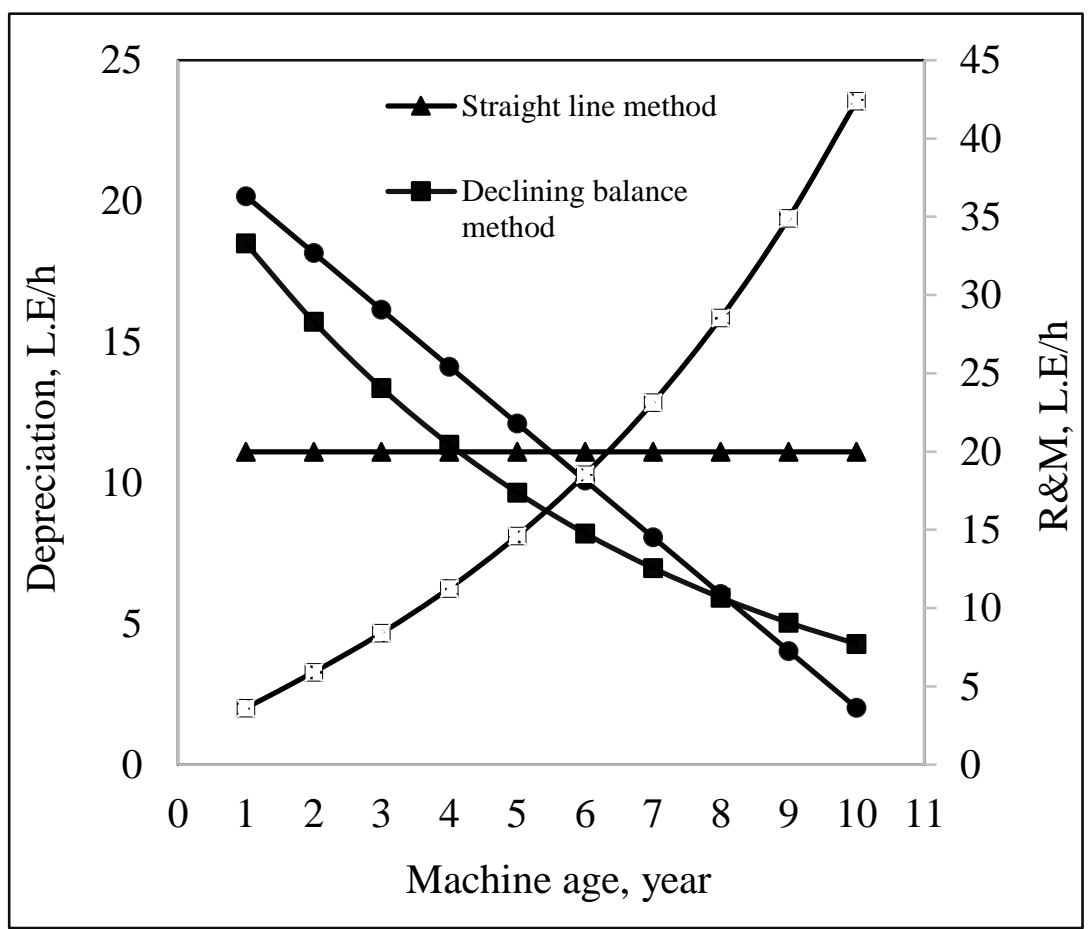

Figure 5: Effect of machine age on depreciation and repair \& maintenance costs of the third system (threshing stage), (L.E/h). 
Table 8. Total operating cost of the third system, at different forward speeds and machine age, L.E./fed.

\begin{tabular}{|c|c|c|c|c|c|c|c|c|c|c|c|c|}
\hline \multirow{4}{*}{$\begin{array}{l}\text { Machine } \\
\text { age, year }\end{array}$} & \multicolumn{12}{|c|}{ Total cost, L.E/fed } \\
\hline & \multirow{2}{*}{\multicolumn{4}{|c|}{\begin{tabular}{|l} 
Straight line method \\
Forward speed, km/h
\end{tabular}}} & \multirow{2}{*}{\multicolumn{4}{|c|}{$\begin{array}{c}\text { Declining balance method } \\
\text { Forward speed, } \mathbf{k m} / \mathrm{h}\end{array}$}} & \multirow{2}{*}{\multicolumn{4}{|c|}{$\begin{array}{l}\text { sum of the years' digits } \\
\text { Forward speed, km/h }\end{array}$}} \\
\hline & & & & & & & & & & & & \\
\hline & 1.85 & 2.54 & 3.44 & 4.25 & 1.85 & 2.54 & 3.44 & 4.25 & 1.85 & 2.54 & 3.44 & 4.25 \\
\hline 1 & 160.69 & 124.69 & 94.97 & 80.84 & 199.92 & 154.56 & 117.21 & 99.54 & 208.84 & 161.35 & 122.27 & 103.79 \\
\hline 2 & 169.82 & 131.64 & 100.14 & 85.19 & 194.34 & 150.31 & 114.05 & 96.88 & 207.27 & 160.16 & 121.38 & 103.04 \\
\hline 3 & 179.50 & 139.01 & 105.63 & 89.80 & 191.51 & 148.16 & 112.45 & 95.53 & 206.25 & 159.38 & 120.80 & 102.55 \\
\hline 4 & 190.34 & 147.27 & 111.78 & 94.97 & 191.72 & 148.32 & 112.57 & 95.63 & 206.39 & 159.49 & 120.88 & 102.62 \\
\hline 5 & 202.73 & 156.70 & 118.81 & 100.88 & 195.08 & 150.88 & 114.47 & 97.23 & 208.08 & 160.78 & 121.84 & 103.43 \\
\hline 6 & 217.03 & 167.59 & 126.91 & 107.69 & 201.70 & 155.91 & 118.22 & 100.38 & 211.68 & 163.51 & 123.88 & 105.14 \\
\hline 7 & 233.59 & 180.20 & 136.30 & 115.58 & 211.73 & 163.55 & 123.91 & 105.17 & 217.54 & 167.98 & 127.20 & 107.93 \\
\hline 8 & 252.81 & 194.84 & 147.20 & 124.75 & 225.40 & 173.97 & 131.66 & 111.68 & 226.06 & 174.47 & 132.03 & 112.00 \\
\hline 9 & 275.13 & 211.83 & 159.86 & 135.39 & 243.01 & 187.37 & 141.64 & 120.07 & 237.68 & 183.32 & 138.62 & 117.54 \\
\hline 10 & 301.05 & 231.58 & 174.56 & 147.74 & 264.92 & 204.06 & 154.07 & 130.52 & 252.90 & 194.91 & 147.26 & 124.79 \\
\hline
\end{tabular}

Table 9. Total operating cost of the third system, at different threshing drum speeds and machine age, L.E./fed.

\begin{tabular}{|c|c|c|c|c|c|c|c|c|c|c|c|c|}
\hline \multirow{4}{*}{$\begin{array}{l}\text { Machine } \\
\text { age, year }\end{array}$} & \multicolumn{12}{|c|}{ Total cost, L.E/fed } \\
\hline & \multirow{2}{*}{\multicolumn{4}{|c|}{$\begin{array}{c}\text { Straight line method } \\
\text { Threshing drum speed, } \mathrm{m} / \mathrm{s}\end{array}$}} & \multirow{2}{*}{\multicolumn{4}{|c|}{$\begin{array}{l}\text { Declining balance method } \\
\text { Threshing drum speed, } \mathbf{m} / \mathbf{s}\end{array}$}} & \multirow{2}{*}{\multicolumn{4}{|c|}{$\begin{array}{c}\text { sum of the years' digits } \\
\text { Threshing drum speed, } \mathrm{m} / \mathrm{s}\end{array}$}} \\
\hline & & & & & & & & & & & & \\
\hline & 25 & 28.8 & 32.6 & 34.4 & 25 & 28.8 & 32.6 & 34.4 & 25 & 28.8 & 32.6 & 34.4 \\
\hline 1 & 546.52 & 498.49 & 453.98 & 441.17 & 576.52 & 524.61 & 476.64 & 462.52 & 583.34 & 530.54 & 481.79 & 467.37 \\
\hline 2 & 555.81 & 506.57 & 461.00 & 447.78 & 574.56 & 522.90 & 475.15 & 461.12 & 584.44 & 531.50 & 482.62 & 468.16 \\
\hline 3 & 565.93 & 515.39 & 468.64 & 454.99 & 575.12 & 523.39 & 475.58 & 461.52 & 586.39 & 533.20 & 484.09 & 469.54 \\
\hline 4 & 577.55 & 525.50 & 477.41 & 463.25 & 578.61 & 526.42 & 478.21 & 464.00 & 589.82 & 536.19 & 486.68 & 471.98 \\
\hline 5 & 591.09 & 537.29 & 487.64 & 472.88 & 585.24 & 532.20 & 483.22 & 468.72 & 595.18 & 540.85 & 490.73 & 475.79 \\
\hline 6 & 606.97 & 551.11 & 499.63 & 484.18 & 595.25 & 540.91 & 490.78 & 475.84 & 602.88 & 547.55 & 496.54 & 481.27 \\
\hline 7 & 625.63 & 567.37 & 513.72 & 497.47 & 608.92 & 552.81 & 501.10 & 485.57 & 613.36 & 556.68 & 504.46 & 488.73 \\
\hline 8 & 647.58 & 586.47 & 530.30 & 513.08 & 626.63 & 568.23 & 514.47 & 498.17 & 627.13 & 568.67 & 514.85 & 498.53 \\
\hline 9 & 673.38 & 608.93 & 549.78 & 531.44 & 648.82 & 587.55 & 531.23 & 513.96 & 644.74 & 584.00 & 528.15 & 511.06 \\
\hline 10 & 703.67 & 635.31 & 572.65 & 552.99 & 676.04 & 611.25 & 551.79 & 533.33 & 666.86 & 603.25 & 544.85 & 526.80 \\
\hline
\end{tabular}




\section{REFERENCES}

ASABE Standard, (2004). Agricultural machinery management. ASABE D496.2 data. p. 367-372. In: ASAE, St. Joseph, MI, USA.

ASABE Standard, (2006). Agricultural Machinery Management. ASABE EP496.2, ASABE, St. Joseph, MI.

Bowers, W. (1981). Fundamentals of Machine Operation (FMO): Machinery Management. $2^{\text {ed }}$ edition. Deere \& Company. Moline. IL. USA.

Edwards, W. (2005). Farm machinery economic cost estimates for late. Extension farm management specialist. Nebraska Univ. Co. of Ag. and Env. Sci.

Hunt, D. (1979). Farm power and machinery management. $8^{\text {th }}$ edition., Iowa State University. Press Ames.

Hunt, D. (1983). Farm power and machinery management $9^{\text {th }}$ ed. Iowa State Univ. Press, Ames.

Ismail, Z.E., M.M. Ibrahim and S.A. Embaby (2009). Economic evaluation and selection of farm machinery. Misr J. Ag. Eng., 26(4): 1667-1681

Kepner, R.A., R. Bainer and E.L. Barger. (1982). Principles of farm machinery, $3^{\text {rd }}$ edition. The AVI publishing Co. Inc. West Port, Connecticut, USA.

Witney, B.D. and T. Saddaoun (1989) Annual cost of farm machinery ownership. Scotland center of Agricultural engineering (ACAE). East of Scotland collage of Agricultural, Edinburgh. 


\section{الملخص العربي}

\section{تحليل تكاليف التشغيل لبعض نظم الحصاد في مصر}

م. حمادة عادل مرجان****، أ.د. محمد الشحات بدوي ** و أ.د. إسماعيل أحمد عبد المطلب *

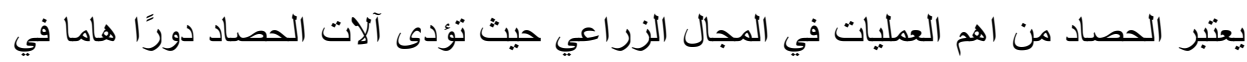

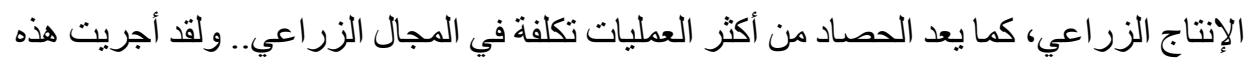
الدر اسة لتحديد وتحليل اهم العوامل المؤثرة على تكاليف التشغيل الكلية لاهم ثلاثنة نظم لحصاد

$$
\text { القمح في مصر وهي: }
$$

ا ـ النظام الأول: الة الحصاد الجامعة متعددة الأغراض. r. النظام الثاني: المحثة الترددية المعلقة على الجرار + الة الاراس الثابتة. r. النظام الثالث: الة الحصاد والتربيط + الة الاراس الثابتة. كما تم في هذه الدر اسة تقدير تكاليف الاستهلاك (جنيه/ساعة) بثلاث طرق مختلفة وهي طريقه الخط المستقيم وطريقة الميز ان المتناقص وطريقة مجموع ارقام السنين ونأثير ذلك على أجمالي تكاليف التشغيل الكلية (جنيه/فدان).

\section{أظهرث النتائج المتحصل عليها ما يلي:-}

أوضحت النتائج انه في حالة النظام الأول وذللك عند سرعة ه, ع كم/ساعة بلغت اقل قيمة

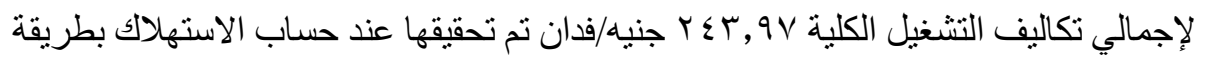

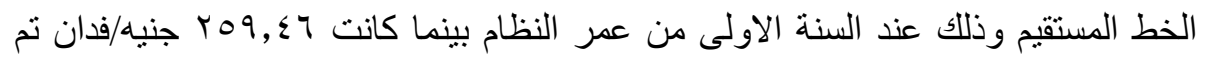

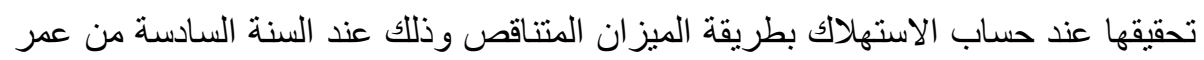
النظام بينما كانت اقل قيمة لإجمالي تكاليف التشغيل الكلية في حالة حساب الاستهلاك بطريقة مجموع ارقام السنين IVY,Y جنيه/فدان وذللك عند السنة الثامنة من عمر النظام. اما في حالة النظام الثاني وذللك عند سرعة امامية بr, ع كم/ساعة وسرعة درفيل الدر اس

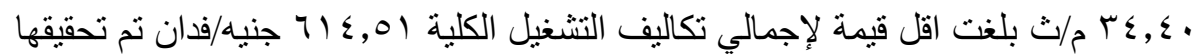
عند حساب الاستهلاك بطريقة الخط المستقيم وذلك عند السنة الاولى من عمر النظام بينما

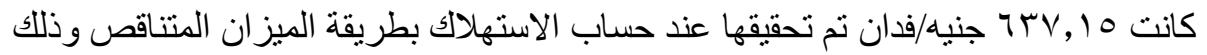
عند السنة الثانية من عمر النظام بينما كانت اقل قيمة لإجمالي تكاليف التشغيل الكلية في حالة

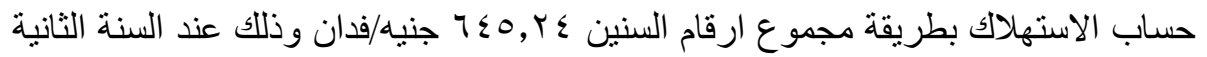
من عمر النظام.

"أستاذ الهندسة الزراعية ـ كلية الزراعة ـ جامعة كفر الثيخ.. * * *ئيس بحوث - معهد بحوث الهندسة الزراعية ـ مركز البحوث الزراعية ـ الجيزة.

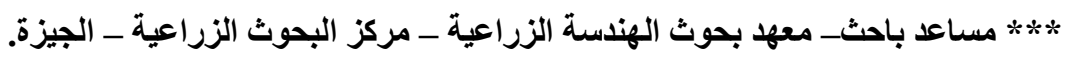




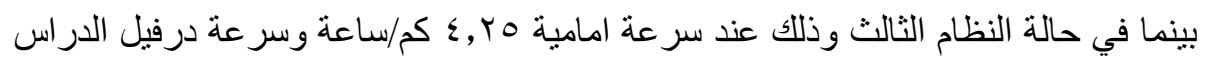

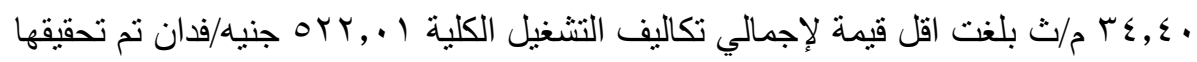

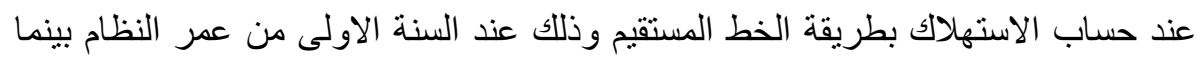

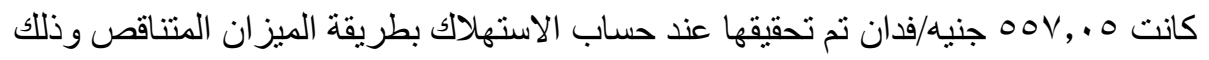

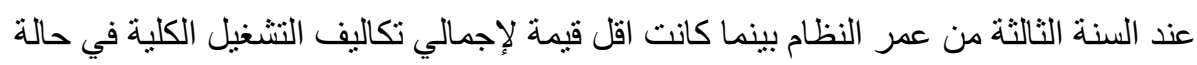

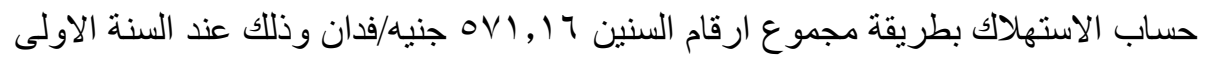
من عمر النظام. من خلال هذه الدراسة نوصى باستخدام النظام الأول في حالة الحياز ات الكبيرة، اما في حالة الحياز ات الصغيرة نوصى باستخدام النظام الثالث. 